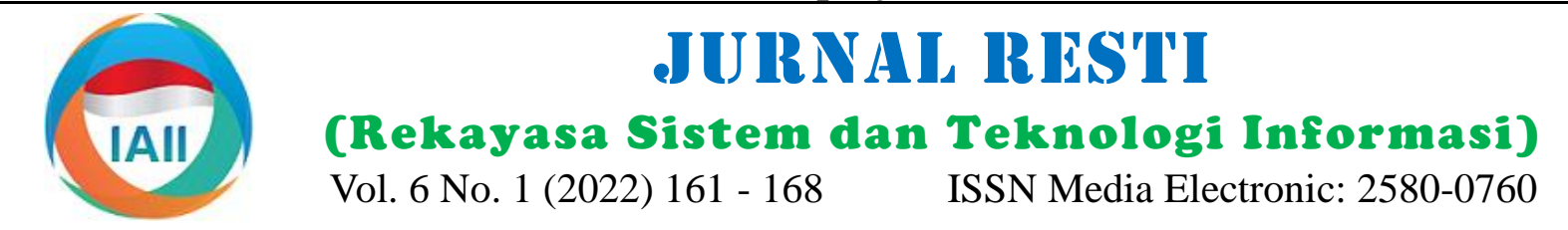

\title{
Management Administration Smartphone Application as a Strategy to Increase Accreditation Score in Primary Healthcare Facilities
}

\author{
Agus Sugiharto $^{1}$, Boy Subirosa Sabarguna ${ }^{2}$, Ajeng Pramastuty ${ }^{3}$ \\ ${ }^{1,2}$ Department of Community Medicine, Faculty of Medicine, Universitas Indonesia \\ ${ }^{3}$ Faculty of Engineering, Universitas Indonesia \\ 11agus.sugiharto@ui.ac.id*,2sabarguna08@ui.ac.id, ${ }^{3}$ ajeng.pramastuty81@ui.ac.id
}

\begin{abstract}
Health facility accreditation has been in great demand in recent years. Mobile applications can serve as a tool for community healthcare center's (Puskesmas) to assess the value of their accreditation, especially regarding administration and management. In the context of preparation for accreditation, it can be used as a self-assessment tool for elements of management administration. This case-based article focuses on smartphone application development using the input-processoutput-outcome scheme as a framework. We developed a checklist and assessment for the management administration component by reviewing Permenkes No. 46 the Year 2015 concerning Puskesmas accreditation. This is the first available mobile application on the Google Play Store, targeting Puskesmas staff to improve the quality of administration and management services based on accreditation criteria. This smartphone application functions as an independent assessment tool for Puskesmas to complete the accreditation criteria as stated in the regulation of the minister of health. About 20 Puskesmas staff showed a very good response and positive. All stated that they were very helpful and satisfied with this application, so they will continue to use and distribute it to other Puskesmas staff.
\end{abstract}

Keywords: administration, management, Puskesmas, accreditation, smartphone application.

\section{Introduction}

Health care is the right of every Indonesian citizen which is guaranteed by the 1945 Constitution of the Republic of Indonesia. This right must be realized through efforts to improve public health as high as possible. January 2014, Indonesia entered the era of a new health system with the implementation of the National Social Security System (SJSN) for Healthcare and Social Security Agency (BPJS).

With the existence of BPJS, the number of patients treated by health care institutions, both at the primary, second and advanced levels has increased significantly. There has been a significant increase in the number of participants since the start of the National Health Insurance (JKN) program, which increased from 133 million in 2014 to 208 million at the end of 2018 [1]. In 2020 , the number of participants in the JKN program organized by BPJS Health reached 222.5 million people. This figure is equivalent to $81.3 \%$ of the population in Indonesia [2]. There was an increase in the use of first-rate outpatient services (RJTP) by $155 \%$, from 1,022 per 10,000 in 2014 to 2,607 per 10,000 in 2018 [1]. RJTP is carried out in primary healthcare.
Primary healthcare is a health facility that provides individual health services with non-specialist services for observation, diagnosis, treatment, and other health services. Primary healthcare includes public primary health facilities, a Pratama clinic, a dentist's independent practice [3]. An increase in the number of patients who come to primary health facilities must be followed by an increase in the quality of health services.

There are many strategies to drive improvements in primary care. One is to use external assessment mechanisms such as accreditation. Accreditation that has been and is often widely applied both internationally and nationally is hospital accreditation, Accreditation for primary services is still very limited [4]. Studies conducted by Alkhenizan \& Shaw, (2011) states that consistent accreditation can provide excellent results in improving and improving the quality of health services. Other studies conducted by Ghareeb et al., (2018) found that accreditation has a positive impact both for improving the quality of services and providing learning in organizations running good health services.

Primary health services in Indonesia are run mainly by public primary health facilities commonly known as

Accepted: 02-02-2022 | Received in revised: 24-02-2022 | Published: 27-02-2022 
Puskesmas and a small number by private clinics and private practices. Health centers in Indonesia have increased from 9,754 in 2015 to 10,166 in 2020 [7]. Therefore, all Puskesmas must be accredited. Data for 2019 from 10062 new Health Centers 9153 that have been accredited, of which $24 \%$ have basic (dasar) graduation status, intermediate (Madya) 55\%, Main (utama) 18\%, and high (paripurna) 3\% [7].

The Minister established Regulation of Minister of Health No 46 the Year 2015 which contains several standards related to the provision of health services in primary healthcare. One of the main objectives of puskesmas accreditation is to guide quality improvement, performance through continuous improvement of management systems, quality management systems, and service delivery systems and programs, as well as the application of risk management [3], and not just an assessment to get an accreditation certificate. One of these standards concerns the administration of Puskesmas management, which is in Chapters 1, 2, and 3 of the puskesmas accreditation standards. Chapters 1, 2, and 3 contain service planning according to community needs, access and implementation of Puskesmas activities, governance, management of Puskesmas, improving the quality and performance of Puskesmas [3]. The performance of an organization is closely related to the quality management of service [8]. Lega et al., (2013) in their study found a positive relationship between organizational governance, leadership, management performance, and service quality management, as well as a study conducted by Parand et al., (2014) and El Nahas et al., (2018). So it is clear that management administration is closely related to improving the quality of health services in the accreditation of health facilities, especially Puskesmas. Accreditation is positively related to the improvement of the structure, organization, and service of better health facilities [5], [12]. Therefore, an accredited health facility with full marks ("paripurna") will provide a good system of administration and management. In standard accreditation, every activity must be recorded and documented. Problems arise, whereas one of the organizations in health services, Puskesmas are not accustomed to documenting and often experience difficulties in processing documents for both internal and external needs [13]. So it is necessary to strive to improve document management that is efficient, fast, easy, accurate, and secure. One of the biggest obstacles faced by the Puskesmas in accreditation activities is the problem of document preparation. This also has an impact on the assessment by the surveyor, because of the limited time in checking all the documents owned by the Puskesmas. Accreditation preparation costs are expensive because they must be printed and arranged in folders, and then must be discarded because they are no longer valid for use in subsequent accreditation activities. If it is maintained for storage, it will need storage and maintenance. Therefore, to facilitate the initial assessment survey and document tracing, it is necessary to have a management administration application to support the accreditation of the Puskesmas.

Every year the use of smartphones continues to increase, especially after the Covid-19 attack. In Indonesia, internet users reach 175.4 million people. The number of smartphones connected to the internet has reached 338.2 million units [14]. This is also the case in the medical community, where various mobile health applications are growing rapidly in various countries [15].

In all areas of health and medicine, there is a growing interest in the use of digital applications and in methods for evaluating their quality [16]. Around the world, there are many digital applications available for health, but most applications are about medical education, medical records, consultation, communication, disease management, early detection, health education, health promotion, reminders to take medication and visits, references, and information collection, patient management and monitoring, and mosquito tracking application [17]-[21]. There are still few applications for accreditation. If there is, the only application for accreditation of education or study programs [22]-[26]. While the use of applications regarding health service accreditation is not yet known by many people and institutions, especially regarding assessing management administration to support accreditation of health services in primary services, health centers, and clinics. By using the concept of a checklist tool in the ISO 9001 audit process, we developed an application that helps the accreditation process, especially regarding administration and management in Puskesmas. This type of application in Indonesia does not yet exist to assess the administration and management of healthcare services in accreditation, which of course will be very useful for assessing preparation for accreditation. With government regulations for accreditation in primary health care, there is no doubt that health care facilities and managers need help tools to manage documents and match them with chapters and forms in accreditation.

\section{Research Methods}

\subsection{Study Design}

This is action research for developing web-based and smartphone-based applications and testing applications to the user. We use the framework from input-processoutput-outcome, as follow (Figure 1):

Input: data according to the Administration and Management accreditation form (Chapters I, II, III) in Puskesmas. 
Process: software application.

Output: mobile health application and decision support system.

Outcome: Puskesmas fulfilled accreditation criteria for the Administration and Management accreditation form (Chapters I, II, III).

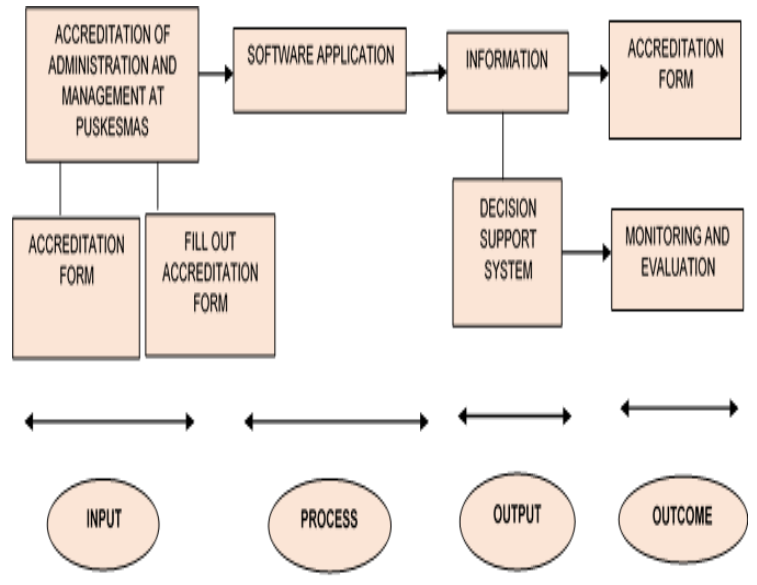

Figure 1. Diagram Process of Workflow

\subsection{Study Subjects}

We tested this application on five programmers, to test the system. We give them a link to download the application and send consents and inquiries informed by email. For direct users, we hold outreach events to promote this application. We send invitations to the District Health Office, which they will distribute to all Puskesmas in Jakarta, including district and sub-district health centers. We ask each other's representatives Puskesmas, especially those who are involved in developing administrative and management strategies at the Puskesmas. This is a pilot project, therefore, we limiting the quota to 20 Puskesmas, and that will be expanded later after we receive feedback from endusers.

\subsection{Location and Time}

Trials and evaluations for end-users take place online with zoom in December 2020. As for programmers, the evaluation was done independently and the results were obtained via email. The overall duration of this research was ten months, with the first six months for software development, and the rest for testing, promotion, and evaluation.

\subsection{Accreditation form}

The accreditation form consists of administrative and management indicators as described in Chapters 1, 2, 3 in the Regulation of Minister of Health No 46 the Year 2015. It contains 59 indicators in Chapter 1, 121 indicators in Chapter 2, and 32 indicators in Chapter 3. Internal and/or external documents were used to meet the criteria in each indicator.

\subsection{Software Development}

The development team develops the content and the results from the content development were transferred to the application development team to build the software. The framework used for content development comes from Chapters 1, 2, 3 of the Minister of Health Regulation no. 46 of 2015. The Base Application Design is divided into two parts: 1) introduction and 2) content.

In the introduction, users can login by registering their email and identity. Users must register their institution, in this case, the Puskesmas/clinic. Before entering the application, the user will find a disclaimer stating the adoption of this application from Chapter 1, 2, 3 of the Minister of Health Regulation No. 46 of 2015. On the front page, users can find the developer team's email address for discussion and asking questions. Video tutorials and manuals are also provided here.

It contains 59 indicators in Chapter 1, 121 indicators in Chapter 2, and 32 indicators in Chapter 3, as described in the regulation. The user can select an indicator and go to the rating page for that indicator. On the assessment page, there will be an explanation of the indicators. We include all the indicators mentioned in the sub-chapters and their components. There are requirements in each indicator to meet certain documents. An additional function is to upload documents embedded in this application, where users can upload the required documents from a computer to a smartphone by scanning a QR code in the application. On the indicator, there will be a green mark if all the required documents have been uploaded. If the requirements have not been completed, the user will be seen on the screen the progress achieved from uploading documents for accreditation.

The user can right-click on the top of the indicator page after fulfilling all the required documents in all the indicators. Then you will see the score. Zero is the score given when not a single document is uploaded, five is the score given when only a partial document is uploaded. While a score of 10 is given if the uploaded document meets all the requirements. If all the criteria are met, then the user will get a full score. The resulting score in this application will be the basis of the decision support system. The decision support system will provide useful recommendations and suggestions on things that need to be improved.

\subsection{Evaluation of mobile application}

Evaluate this application by testing it on the programmers and end-users. The programmer that will test the functionality of the application is a programmer who is experienced in developing smartphone applications. We select programmers in order. The

DOI: https://doi.org/10.29207/resti.v6i1.3847

Creative Commons Attribution 4.0 International License (CC BY 4.0) 
appearance, function, accessibility, logical system, and applicability were all evaluated by programmers. A questionnaire was utilized to measure general features, system features, and features of accreditation function. The Programmers would give scores 1 to 4 for each component, with a score of 4 as the most satisfied and 1 as the least satisfied.

Meanwhile, the end-users here are Puskesmas officers who are in charge of administration and management systems at their facilities. We asked each Puskesmas staff to fill out a set of questionnaires and rate them using a Likert scale to measure their expectations and level of satisfaction.

\section{Results and Discussions}

\subsection{Results}

\subsubsection{Application System}

The Health mobile application entitled "AKSES 2021" Accreditation Puskesmas. Users can easily find and download this app directly on Google Play Store. The language used in this application is Indonesian because it is intended for Puskesmas staff.
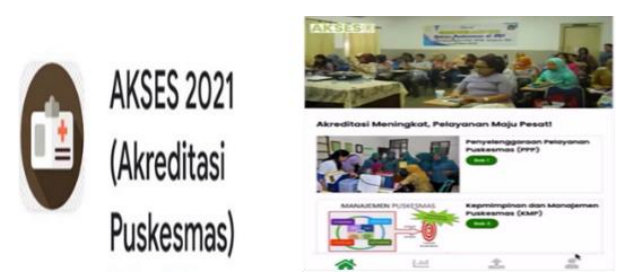

Figure 2. Front Display of AKSES 2021

When the user opened the application, he/she can only see the home page and chapter details. Meanwhile, the progress, upload, and other features require a login. Users are welcome to log in first.

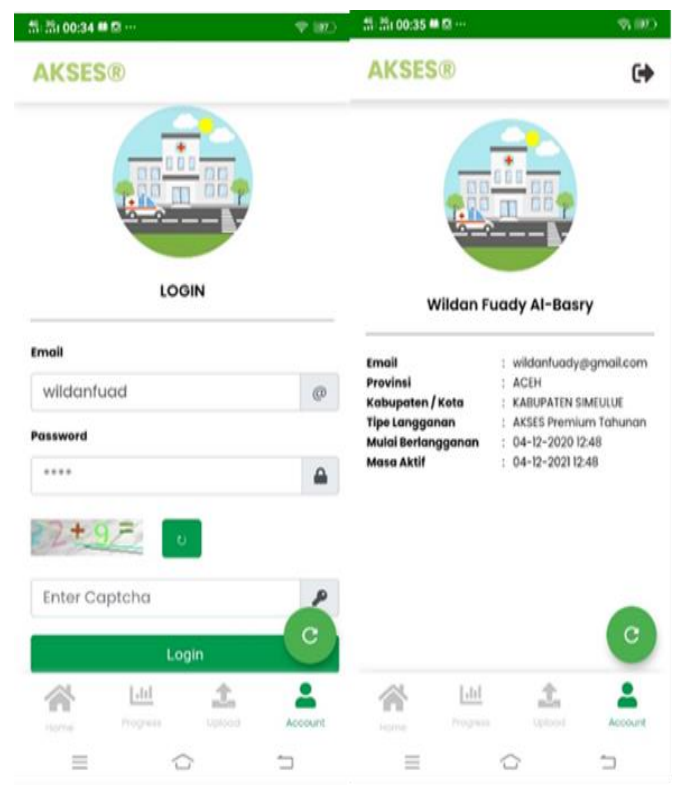

Figure 3. Login and Profile Page
After successful login, the profile details will be displayed. Where you will see your name, email, address, and active period.

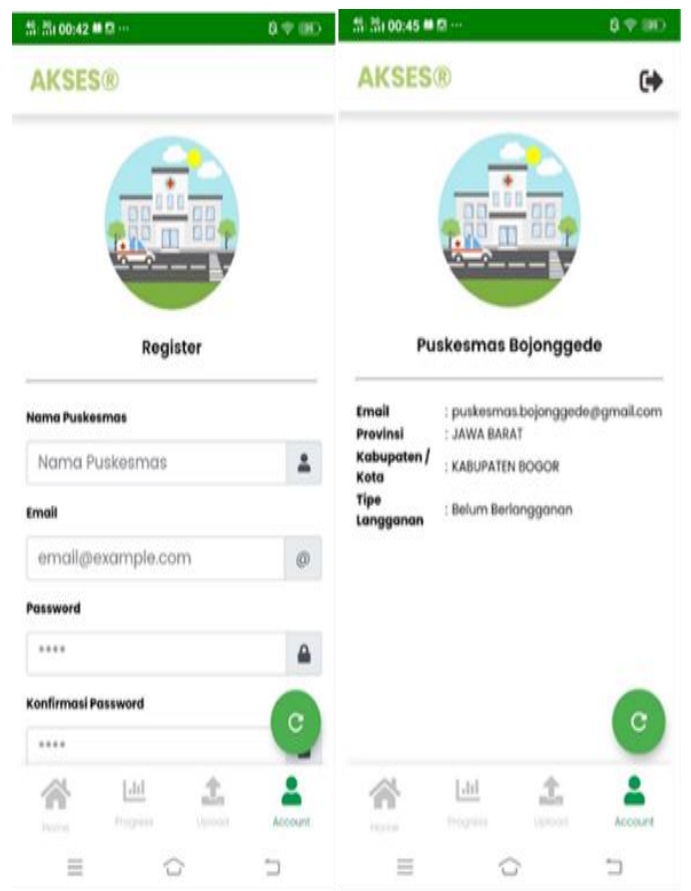

Figure 4. Registration Page and Puskesmas

If you don't have an account yet, the user can select register in the account menu and after that, the name and address of the puskesmas will appear.

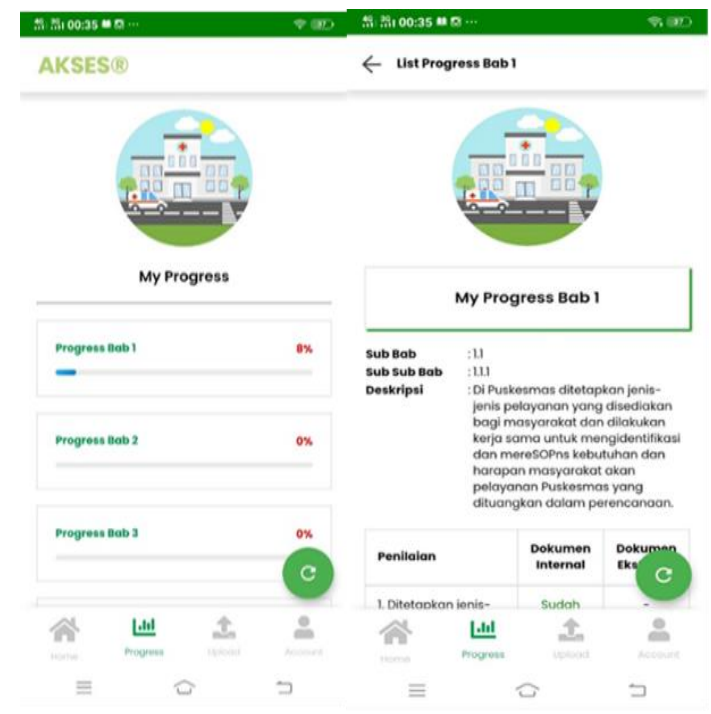

Figure 5. Progress Page

The user then fills in the indicator and uploads the document according to the accreditation requirements. The users after filling in the indicators and uploading documents can see the progress of accreditation in the progress menu. Here we will be faced with several Chapters 1, 2, 3 along with the progress of uploading accreditation documents. To find out the details, users

DOI: https://doi.org/10.29207/resti.v6i1.3847

Creative Commons Attribution 4.0 International License (CC BY 4.0) 
can click on each chapter. The users can view information on each chapter and sub-chapter regarding what documents are required to be submitted in the accreditation process. After reading what documents need to be prepared, the user can upload the file on the upload menu and can enter the Chapter, Sub-Chapter, and Sub-Sub-Chapter that they want to process the document. After selecting, you can directly upload the document. Select "Ya" every time you want to upload each document.

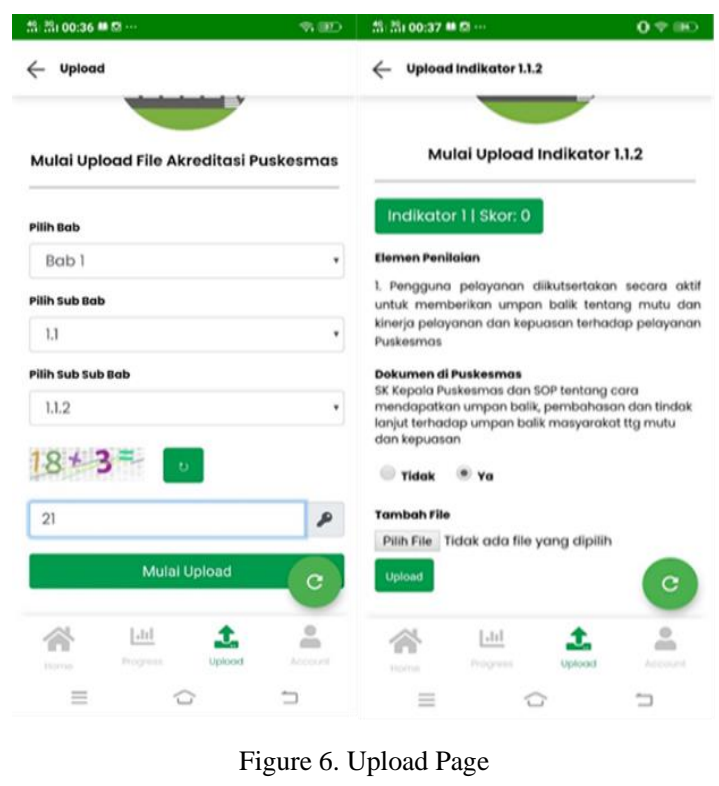

\subsubsection{Evaluation Result}

Five programmers were selected to test the application and fill out a questionnaire. The Table 1. Summarizes the result. Overall score, the programmers show satisfaction. In addition, we also ask for their input to improve everything in the application. There were some inputs from programmers, especially on the filling order and system process in the accreditation system. They suggested the tab menu to be more user-friendly and followed the data process. The programmers suggested adding more options and slots for uploading documents. For example, there should be an option to upload documents from a smartphone or use photos related to the required accreditation documents. If only a few options and slots will make it unfriendly and difficult if other supporting documents are needed for users. So hopefully it will be more effective.

To use and understand the eligibility of this accredited mobile app. We also conducted a pilot on Puskesmas staff (Table 2). We distributed questionnaires to 20 Puskesmas staff, with each staff representing one Puskesmas. We distributed the questionnaire via a Google form link and asked respondents to complete it. We carry out promotions and outreach through zoom meetings to the Puskesmas regarding the use of this mobile application. The Likert scale is used to measure respondent satisfaction with the appearance and functionality of this accreditation application. Zero means strongly disagree and four means strongly agree.

Table 1. Evaluation Result from Programmers

\begin{tabular}{lll}
\hline No & Question & $\begin{array}{l}\text { Mean score of } \\
\text { programmer }\end{array}$ \\
\hline General features & \\
$\mathbf{1}$ & Access & 3.6 \\
$\mathbf{2}$ & Speed access & 3.4 \\
$\mathbf{3}$ & General appearance & 3.4 \\
$\mathbf{4}$ & The logic of the & 3.6 \\
& program & \\
$\mathbf{5}$ & Main menu & 3.6 \\
System features & \\
$\mathbf{1} \quad$ Logic system & 3.4 \\
$\mathbf{2}$ & Filling order & 3.4 \\
$\mathbf{3}$ & Input data & 3.2 \\
$\mathbf{4}$ & System process & 3.2 \\
$\mathbf{5}$ & App system appearance & 3.4 \\
$\mathbf{F e a t u r e s ~ o f ~ A c c r e d i t a t i o n ~}$ & \\
$\mathbf{1}$ & Logic system & 3.4 \\
$\mathbf{2}$ & Filling order & 3.2 \\
$\mathbf{3}$ & Input data & 3.0 \\
$\mathbf{4}$ & System process & 3.0 \\
$\mathbf{5}$ & Appearance features of & 3.4 \\
\hline \multicolumn{2}{l}{ Accreditation } \\
\hline
\end{tabular}

Table 2. Evaluation Result from Staff Puskesmas

\begin{tabular}{|c|c|c|}
\hline No & Question & $\begin{array}{l}\text { Mean } \\
\text { score }\end{array}$ \\
\hline \multicolumn{3}{|c|}{ App ease of use } \\
\hline 1 & Front display of application & 3.9 \\
\hline 2 & Easy to register to the application & 3.8 \\
\hline 3 & $\begin{array}{l}\text { Easy to understand the definition of each } \\
\text { column and button function of each indicator }\end{array}$ & 3.8 \\
\hline 4 & Easy to upload the document & 3.85 \\
\hline \multicolumn{3}{|c|}{ App benefits } \\
\hline 1 & $\begin{array}{l}\text { This application corresponds with Puskesmas } \\
\text { needs }\end{array}$ & 3.85 \\
\hline 2 & $\begin{array}{l}\text { This application can improve Puskesmas } \\
\text { performance }\end{array}$ & 3.9 \\
\hline 3 & $\begin{array}{l}\text { This application can encourage us to be } \\
\text { independent in implementing the } \\
\text { accreditation program }\end{array}$ & 3.9 \\
\hline 4 & $\begin{array}{l}\text { This application could help to prepare } \\
\text { accreditation in Puskesmas }\end{array}$ & 3.9 \\
\hline 5 & $\begin{array}{l}\text { This application can increase the local } \\
\text { potential to achieve the target of the } \\
\text { accreditation }\end{array}$ & 3.9 \\
\hline \multicolumn{3}{|c|}{ Independent use of the app } \\
\hline 1 & $\begin{array}{l}\text { We could use this application independently } \\
\text { (without help from UI) }\end{array}$ & 3.8 \\
\hline \multicolumn{3}{|c|}{ Information about the app } \\
\hline 1 & Understanding of application manual book & 3.75 \\
\hline 2 & $\begin{array}{l}\text { UI team provides clear information about this } \\
\text { application }\end{array}$ & 3.9 \\
\hline \multicolumn{3}{|c|}{ Satisfaction about the app } \\
\hline 1 & Satisfaction level for application & 4 \\
\hline
\end{tabular}

The Table 2. Summarizes the result. Overall score, showed satisfaction. All respondents were very enthusiastic about using and disseminating information about this application to their friends from other Puskesmas officers. However, there are some difficulties in using this application, for example, 1) option to cancel document upload; 2) difficulty in uploading the required documents for each indicator because they have to use a computer; 3) unavailability in the apple store. Respondents suggested adding a

DOI: https://doi.org/10.29207/resti.v6i1.3847

Creative Commons Attribution 4.0 International License (CC BY 4.0) 
function to make it easier to upload documents so that it can be done via smartphones; addition of other accreditation components; adding documents for reference; ability to check document validity and add places to save other files as needed. Despite all the weaknesses of this application, all respondents agreed that this application will be very helpful in monitoring the progress of completing the documents required for accreditation.

This application is the first and specifically accommodates the need for Puskesmas to assess administration and management in support of accreditation. Therefore, this application was tested on Puskesmas staff who were the target users of this application. By using this application, Puskesmas officers can monitor their performance in administration and management independently. However, we realize that in this application of course some shortcomings exist and must be improved again to make it better and more effective. First, this application only focuses on Chapters 1, 2, 3, and does not include any other chapters. While in accreditation, some of the required documents can be linked to other chapters as well. Second, the application currently does not have a function to check whether the user has uploaded the correct document according to the indicator or not. Users can indeed save, upload, and download the required documents; however, they do not understand the validity of the document. Third, since this is a trial version, it is currently only available on the Google Play Store. Use of this app will be extended to a larger target audience, will also be featured in the Apple Store and by adding other accredited Chapters.

\subsection{Discussion}

Accreditation of health services is very important for all stakeholders [27]. This is because the results of accreditation are one of the quality indicators and references in making decisions for various needs including improving the quality of health services in the future [28]. For a primary service institution, for example, Puskesmas, accreditation helps to determine the extent to which it has met the quality criteria set by the government or national standards as a minimum quality standard; as a reference for all parties to the Community Health Center to evaluate performance and short-term and long-term planning; as a basis for making improvements and improving the quality of health services in the future as part of continuous quality improvement; and as a form of compliance with regulations set by the government and as part of public accountability [29]-[31]. For the community, accreditation is no less important because they are the main customers of a health service. One of the reasons why accreditation is important for the community is because the results of the accreditation describe the service quality of a Puskesmas. Thus, the community can find out and choose which Puskesmas to serve for health services.

The management of the accreditation information system so far is still done manually, this is still a collection of documents in physical form that exist in every Puskesmas. Physical documents will cause many problems, in addition to storage space, easily damaged and lost, will also cause large costs in the preparation of accreditation documentation [32]. The application provides solutions for Puskesmas, as one of the primary services in preparing for accreditation. All programmers state that this application provides convenience, organization of information, and documents required for accreditation requirements. The ease of monitoring the document upload process, thereby minimizing errors and providing accreditation assessments for administration and management, is another strength of our application. In the results of the research, not all form images are displayed considering how complex it is and the number of forms that have been generated from the system. In principle, the data input process is carried out with a process that is not much different to facilitate the process of inputting data and producing output, so that users will interact with the user interface using the buttons on the standard filling form for Puskesmas accreditation Chapters 1, 2, 3.

From the user's point of view, this application is very useful, easy, useful and helps them in preparing for accreditation at the Puskesmas where they work, it can be seen that all Puskesmas staff give an average score above 3.7, even a score of 4 for satisfaction with this application, so they want to continue using it, this is according to research Cho, (2016) and Hsiao et al.,(2016). This application makes it easy for them to upload all the Chapter 1, 2, 3 documents required in the accreditation requirements of the Puskesmas. The advantage of this application is that users can judge for themselves about the preparations that have been made because they can see whether or not the upload process is complete. At the end of this application process, users can find out the value of accreditation, so that later they can prepare and fix what are shortcomings to get a better accreditation assessment.

Despite the usefulness of these studies and applications, there are some limitations. This study only invites programmers, does not invite system analysts and software engineers to test applications. This application applies specifically to designated Puskesmas staff and requires the staff to actively download from Google Play Store. Since it is a mobile app, it will be easy to use for staff who are already familiar with the technology. However, many Puskesmas staff are not familiar with the technology. Therefore, they may ask other staff to download the app. Providing training on application usage for staff may be required in this 
community. In addition, other shortcomings still need to be corrected, especially in checking the certainty of the uploaded documents, whether the documents are following the accreditation requirements. This application can also be added to functions and adapted to changes in chapters, standards, accreditation guidelines if later the accreditation guidelines change.

\section{Conclusion}

This mobile application assesses the administration and management of accreditation at the smartphone-based Puskesmas, which is very easy to use and useful for the Puskesmas to achieve accreditation based on data the Regulation of Minister of Health No 46 the Year 2015. All Puskesmas staff can easily upload documents and monitor their activities through this mobile application. This application will also be able to assess the preparation for accreditation, so that later when the accreditation is carried out it will be better and get a good accreditation score. Therefore, realizing the needs of Puskesmas and the benefits of this application, we will recommend the wider use of this application to Puskesmas and other clinics. More and more health centers are affordable, including outside Jakarta. Participants respond they are willing to recommend this application to their colleagues so that more Puskesmas can use this application to monitor their activities and achieve better accreditation results. This is a pilot study to develop systems and test logic systems and process the data. Further study with systems analysts and software engineers is required to evaluate the effectiveness and feasibility of this system.

\section{Acknowledgment}

This study was carried out thanks to a grant from the University of Indonesia. The app is publicly accessible from the Google Play Store. We thank Medcom VisiTama for assisting in developing the mobile application. We also thank the East Jakarta Health Office and the Department of Community Medicine for allowing us to promote this application for Puskesmas staff in DKI Jakarta.

\section{Reference}

[1] BPJS Kesehatan, Statistik JKN 2014-2018, vol. 53, no. 9. 2019.

[2] BPJS, "Jumlah Peserta BPJS Kesehatan Capai 222,5 Juta Orang hingga 2020," Katadata.id, p. 2020, 2020, [Online]. Available: https://databoks.katadata.co.id/datapublish/2021/01/06/jumlahpeserta-bpjs-kesehatan-capai-2225-juta-orang-hingga-

2020\#: :text=Jumlah peserta dalam program Jaminan,sebanyak $132 \% 2 \mathrm{C} 8$ juta orang.

[3] 2015 Kemenkes RI, "Peraturan Menteri Kesehatan No. 46 tentang Akreditasi Puskesmas, Klinik Pratama, Tempat Praktik Mandiri Dokter dan Dokter Gigi.” 2015, [Online]. Available: http://www.slideshare.net/adelinahutauruk7/permenkes-no-46tahun-2015-tentang-akreditasi-puskesmas-klinik-pratamatempat-praktik-mandiri-dokter-dan-dokter-gigi.

[4] M. O’Beirne, K. Zwicker, P. D. Sterling, J. Lait, H. L. Robertson, and N. D. Oelke, "The status of accreditation in primary care," Qual. Prim. Care, vol. 21, no. 1, pp. 23-31, 2013.
[5] A. Alkhenizan and C. Shaw, "Impact of accreditation on the quality of healthcare services: A systematic review of the literature," Ann. Saudi Med., vol. 31, no. 4, pp. 407-416, 2011, doi: 10.4103/0256-4947.83204.

[6] A. Ghareeb, H. Said, and M. El Zoghbi, "Examining the impact of accreditation on a primary healthcare organization in Qatar," BMC Med. Educ., vol. 18, no. 1, pp. 1-8, 2018, doi: 10.1186/s12909-018-1321-0.

[7] Kemenkes RI, "Rencana Aksi 2020-2024," Https://ERenggar.Kemenkes.Go.Id. 2020.

[8] M. S. Macinati, "The relationship between quality management systems and organizational performance in the Italian National Health Service," Health Policy (New. York)., vol. 85, no. 2, pp. 228-241, 2008, https://doi.org/10.1016/j.healthpol.2007.07.013.

[9] F. Lega, A. Prenestini, and P. Spurgeon, "Is management essential to improving the performance and sustainability of health care systems and organizations? A systematic review and a roadmap for future studies," Value Heal., vol. 16, no. 1 SUPPL., pp. S46-S51, 2013, doi: 10.1016/j.jval.2012.10.004.

[10] A. Parand, S. Dopson, A. Renz, and C. Vincent, "The role of hospital managers in quality and patient safety: A systematic review," BMJ Open, vol. 4, 2014, doi: 10.1136/bmjopen-2014005055 .

[11] A. El Nahas, M. Bakr, and N. Shrief, "Relationship between the Quality of Administrative System and Health Care Provided to the Patients among Hospital Managers," Menoufia Nurs. J., vol. 3, no. 2, pp. 17-25, 2018, doi: 10.21608/menj.2018.121021.

[12] F. El-Jardali et al., "The impact of accreditation of primary healthcare centers: Successes, challenges and policy implications as perceived by healthcare providers and directors in Lebanon," BMC Health Serv. Res., vol. 14, no. 1, pp. 1-10, 2014, doi: 10.1186/1472-6963-14-86

[13] M. Misnaniarti and P. K. Destari, “Aspek Penting Akreditasi Puskesmas dalam Mendukung Implementasi Jaminan Kesehatan Nasional," J. Penelit. dan Pengemb. Pelayanan Kesehat., vol. 2, no. 1, pp. 10-16, 2018, doi: 10.22435/jpppk.v2i1.35.

[14] Yuswardi A. Suud, "Digital 2020: Pengguna Internet Indonesia dalam Angka," https://cyberthreat.id/, 2020. https://cyberthreat.id/read/5387/Digital-2020-PenggunaInternet-Indonesia-dalam-Angka.

[15] M. N. Kamel Boulos, A. C. Brewer, C. Karimkhani, D. B. Buller, and R. P. Dellavalle, "Mobile medical and health apps: state of the art, concerns, regulatory control and certification," Online $J$. Public Health Inform., vol. 5, no. 3, pp. 1-23, 2014, doi: 10.5210/ojphi.v5i3.4814.

[16] Q. H. Grundy, Z. Wang, and L. A. Bero, "Challenges in Assessing Mobile Health App Quality: A Systematic Review of Prevalent and Innovative Methods," Am. J. Prev. Med., vol. 51, no. 6, pp. 1051-1059, 2016, doi: 10.1016/j.amepre.2016.07.009.

[17] E. Ozdalga, A. Ozdalga, and N. Ahuja, "The smartphone in medicine: A review of current and potential use among physicians and students," J. Med. Internet Res., vol. 14, no. 5, pp. 1-14, 2012, doi: 10.2196/jmir.1994.

[18] T. L. Lewis and J. C. Wyatt, "MHealth and mobile medical apps: A framework to assess risk and promote safer use," J. Med. Internet Res., vol. 16, no. 9, pp. 1-7, 2014, doi: 10.2196/jmir.3133.

[19] C. L. Ventola, "Mobile devices and apps for health care professionals: uses and benefits," Pharm. Ther., vol. 39, no. 5, p. 356, 2014.

[20] A. Sugiharto, L. C. Khoe, D. M. Trianto, M. A. Muharrom, and R. H. Yudanto, Aplikasi web \& smartphone healthpoint: perangkat lunak kader jumantik. Jakarta: Departemen Ilmu Kedokteran Komunitas Fakultas Kedokteran Universitas Indonesia, 2021.

[21] A. Sugiharto, L. C. Khoe, B. S. Sabarguna, and A. Pramastuty, "Reminder System as a Strategy to Improve Patient's Adherence on Medical Appointment," eJournal Kedokt. Indones., 2019, [Online]. Available: https://doi/org/10.23886/ejki.7.10303.

[22] J. Tanjung, D. Raya, and J. Barat, "Aplikasi Sistem Penyusunan Borang Akreditasi Program Studi (Buku Iii-a)," J. Teh. dan Ilmu 
Komput., vol. 03, no. 09, pp. 98-107, 2014.

[23] J. W. Supit et al., "Rancang Bangun Simulasi Akreditasi Program Studi Berbasis Web," J. Tek. Inform., vol. 15, no. 3, pp. 163-170, 2020, doi: 10.35793/jti.15.3.2020.29669.

[24] J. H. Lubis, R. Muliono, and N. Khairina, "Perancangan Dan Implementasi Aplikasi Sistem Informasi Dokumentasi dan Pelaporan Dokumen Borang Akreditasi Program Studi Pada Universitas Medan Area Program Pkm Diya 2019," J. Inform. Kaputama, vol. 4, no. 1, pp. 83-90, 2020.

[25] K. Budayawan and S. Syukhri, "Perancangan Sistem Informasi Dokumentasi Borang Akreditasi Program Studi," J. Teknol. Inf. dan 2017, [Online]. Available: http://repository.unp.ac.id/id/eprint/15137.

[26] A. Primadewi and M. Hanafi, "Pengelolaan Data Terintegrasi Berdasarkan Instrumen Akreditasi Perguruan Tinggi 3.0 Menggunakan Zachman Framework," J. RESTI (Rekayasa Sist. dan Teknol. Informasi), vol. 4, no. 6, pp. 5-10, 2020, doi: 10.29207/resti.v4i6.2540.

[27] D. Debono et al., "Understanding stakeholders' perspectives and experiences of general practice accreditation," Health Policy (New. York)., vol. 121, no. 7, pp. 816-822, 2017, doi: https://doi.org/10.1016/j.healthpol.2017.05.006.

[28] E. Jaafaripooyan, D. Agrizzi, and F. Akbari-Haghighi, "Healthcare accreditation systems: Further perspectives on performance measures," Int. J. Qual. Heal. Care, vol. 23, no. 6, pp. 645-656, 2011, doi: 10.1093/intqhe/mzr063.

[29] J. Braithwaite et al., "Comparison of health service accreditation programs in low- and middle-income countries with those in higher income countries: A cross-sectional study," Int. J. Oual. Heal. Care, vol. 24, no. 6, pp. 568-577, 2012, doi: 10.1093/intqho/mzs064.

[30] E.-J. F. et al., "The impact of accreditation of primary healthcare centers: successes, challenges and policy implications as perceived by healthcare providers and directors in Lebanon," BMC Health Serv. Res., vol. 14, p. 86, 2014, [Online]. Available: http://ovidsp.ovid.com/ovidweb.cgi?T=JS\&PAGE=reference\& $\mathrm{D}=\mathrm{emed} 12 \& \mathrm{NEWS}=\mathrm{N} \& \mathrm{AN}=24568632$.

[31] M. Bahadori, E. Teymourzadeh, R. Ravangard, and M. Saadati, "Accreditation effects on health service quality: nurse viewpoints," Int. J. Health Care Qual. Assur., vol. 31, no. 7, pp. 697-703, Jan. 2018, doi: 10.1108/IJHCQA-07-2017-0126.

[32] J. K. Mallingkan, F. P. Idris, and H. Habo, “Analisis Pelaksanaan Sistem Manajemen Dokumen Akreditasi (Sismadak) Di Rumah Sakit Dr. Sumantri Kota Pare-Pare," J. Muslim Community Heal., vol. 2, no. 1, pp. 121-132, 2021.

[33] C.-H. Hsiao, J.-J. Chang, and K.-Y. Tang, "Exploring the influential factors in continuance usage of mobile social Apps: Satisfaction, habit, and customer value perspectives," Telemat. Informatics, vol. 33, no. 2, pp. 342-355, 2016, doi: https://doi.org/10.1016/j.tele.2015.08.014.

[34] J. Cho, "The impact of post-adoption beliefs on the continued use of health apps," Int. J. Med. Inform., vol. 87, pp. 75-83, 2016, doi: https://doi.org/10.1016/j.ijmedinf.2015.12.016.

DOI: https://doi.org/10.29207/resti.v6i1.3847 